\title{
Book review: Bogdan Góralczyk, Wielki Renesans. Chińska transformacja i jej konsekwencje, Wydawnictwo Akademickie Dialog, Warszawa 2018, pp. 588
}

\section{Radosław Sokołowski}

A few months ago "Wielki Renesans. Chinska Transformacja $i$ jej konsekwencje" was published by Wydawnictwo Akademickie Dialog. The publication was a long-awaited, promised and extremely interesting position of the well-known Polish sinologist, prof. of International Relations Bogdan Góralczyk. This publication is important, regardless of whether someone is interested in China only shallowly or would like to delve into the secrets of Chinese causes, which in recent decades have contributed to the flourishing of China. The author's education is an excellent base for the issues discussed, he graduated in journalism and sinology. As opposed to many popular journalists or scientists, Góralczyk is one of the few who can boast of fluent knowledge of the Chinese language, which significantly affects the reliability of publications. Many years of experience in diplomacy - being an ambassador in Thailand, Burma and the Philippines gives him a completely different perspective in contrast to external observers. Despite the end of diplomatic functions, he travels to China at least once a year, which he admits in the Introduction. Author was staying in China in 1976 (when Mao Zedong died) and Góralczyk was the first Polish student at a Chinese university. This unique experience and observation possibilities make him perhaps the only person who could write a book in such a reliable way.

Given these facts, there is sometimes a concern that the author will be inclined to deviate from scientific analysis and apply personal reflections or subjective memories. Nothing could be more wrong. Certainly, this book does not shy away from its own interpretation of what is happening in China. However, due to the enormous size of the country, it must also be known that there is no „one” China and we are doomed to a partial perspective by nature. It is worth mentioning that this is not the first publication touching China and Góralczyk as an analyst, he has released many books, articles and publications. Initially reading of nearly 600 pages may deter amateurs of the subject but taking into account the enormity of the state, its history and turbulent metamorphosis, 
especially in the last 100 years, 600 pages seems to be quite normal.

The main purpose of the publication is to show the dynamics of changes and effects for China but also for the world. In the last four decades China has changed out of all recognition what the author has become an eyewitness. In a chronological order, author aims to present the reform process that allowed China to emerge from an isolated, poor and agrarian state. All of facts are supported by economic, political, historical sciences and even cultural studies. It must be admitted that only such an interdisciplinary approach to the topic guarantees a better understanding of the Chinese phenomenon and finding the pillars of success that cannot be questioned even by fierce opponents.

The first chapter shows the true faces of the leaders of the Communist Party of China, he brings to life towering figures such as Mao, Zhou Enlai, and Deng Xiaoping, revealing how their different visions have shaped China's modern destiny. Starting with Mao Zedong, a man responsible for unimaginable crimes, who cynically and cruelly sought power over society. Góralczyk clearly presents the dark years of Mao's reign and criticizes the Great Leap Forward, leaving no understatements, calling it a "great catastrophe". The author does not focus only on the suffering of the Chinese and the negative assessments of those years. He tries to capture Mao's complicated psychic, especially at the end of his life, by citing Polish biographers of Mao - W. Dziak and J. Bayer. Disregarding the numerous flaws in Mao's policy, Góralczyk tries to find any advantages in politics, and rather succeeds in it, specifies: a sense of greatness and independence, displacing Taiwan into a political outsider. Finally, Góralczyk makes it clear that the porter Mao, which hangs on the Tiananmen Gate, has its historical justification.

After quite extensive descriptions of successive Chinese rulers, Góralczyk ends the first chapter on Deng Xiaoping as "a true architect and visionary". I think that Góralczyk reads too much into Deng. Nevertheless, he was incontestably one of the greatest pillars of present success. In relation to Deng, Góralczyk uses many advantageous epithets many times in his entire work, looking for the creator of the current success. Following pages cover many of his statements on various aspects of the governance and reform of the country. The author makes the reader become a witness of subsequent brutal events, the presence of communism and the Cultural Revolution, and the events at Tiananmen Square in 1989. Góralczyk's personal experience of communism yoke, despite all the differences between the People's Republic of Poland and the PRC helps to comprehend the dynamics and logic of events than another Western specialists.

The second and subsequent chapters is a comprehensive and competent description and analysis of China's economic 
reforms and their effects on the global economy. The starting point is the recognition that over the past 30 years, China from an economic backward country, has moved to the position of an economic power second only to the United States in terms of GDP. The author seeks answers to the question of what is the essence of Chinese reforms, why reforms have provided China with an incredibly high and sustained pace of growth, and above all - why it has been so successful. He often sees the DNA of success in Confucianism. Góralczyk often returns to Confucianism, emphasizing its characteristic features, such as: hierarchy, righteousness, cherishing of development, collective action. He emphasizes the mutual determinants and tendencies that shaped Chinese culture rather than the chronological, encyclopedic presentation of the facts.

On the following pages, Góralczyk enumerates tree moments which made a "Copernican Revolution". There are: 1992 globalization breakthrough, 2001 admission into the World Trade Organization and 2008-2012 not intense crisis compared to the USA and Western countries. Author supports his thesis by well-known Chinese essayist, Yu Hua: "China has ended the extreme period of poverty now and starts period of wastage". This speed makes it difficult to adapt to changes, concludes Góralczyk.

The second part of the book clearly highlights the consequences of the entire transformation. The author shows that the period of counterfeiting and copying Western patterns is ending. Instead, a period of innovation is entering, with which China will move outside over time. He gives a example of modern companies such as: Lenovo, Alibaba, Xiaomi and Huawei.

In the following parts of the book, foreign policy and geopolitical strategy are presented. It is worth believing what Góralczyk said about the incorporation of Taiwan, Hong Kong and Macau into China. It seems unlikely that this is not contributing to China's economic and political growth but we must wait until 2049 for full unification. In the last part, the author does not prejudge the future, but presents possible scenarios for the future. Góralczyk uses many of the conclusions from the first part, it raises questions whether the economic and socio-political successes will help in solving growing global problems.

The author discusses and evaluates the Belt and Road Initiative, emphasizing its importance for globalization processes. The main conclusion reached is that the Belt and Road Initiative, as the largest geopolitical strategy of the $21^{\text {st }}$ century, will lead to the creation of a multipolar world order which will replace the current USA-centered unipolar one.

"Wielki Renesans...” tells the history of the PRC not only chronologically, but also coherently combines various aspects: economic, social, political and cultural. 
Telling the intricate history of China on several levels is a challenge that the author undoubtedly met. The great advantage of the work is the presentation of China's state and development prospects against the backdrop of global challenges. Throughout the book, what matters most is the role China plays in rationalizing globalization. The author is inclined to the view that China can significantly help in shaping the desired face of the future. The author sees an increasing tendency in China to focus on a new pragmatism, to take into account the threats resulting from the growing global problems: climate and financial. One of the downsides is that we find little about China's external expansion, military strength or the power structure in the region.

He shares his thoughts, comments on the surrounding reality and often addresses to the reader directly, for example by asking him questions. Góralczyk suggests that we cannot rely solely on economic points. It is impossible to understand China in this way. Knowledge of Chinese cultural factors is needed, emphasizes the author.

I think that Góralczyk's book is extremely important and interesting study addresses issues that are crucial for the future of China. Understanding the Chinese phenomenon, its causes, conditions and effects of an extraordinary civilization leap - in the Western world, including Poland, is superficial, tainted by the traditional view. The author successfully breaks this state of affairs, which is the key value of the book, which goes far beyond the standard study of the Chinese economy. Sometimes I got the impression that Góralczyk idealizes the position of China a bit at the expense of Western countries and the USA, but he should be forgiven.

It should be noted that the bibliographic database used in the reviewed publication is quite broad and includes both historical sources, biographies, memoirs and subject studies. The subject literature used in the reviewed book consists of from publications in Polish, English and Chinese. The advantage of the book is its accessibility even to a layman. It is a pleasure to read it because it is written in an interesting, light and understandable way.

In conclusion, it is worth reaching for this reading, the more so as the facts are inexorable. China will overtake the economy of the United States, and according to the forecasts of the World Bank, in 2030 it will become the world's first economic power and one of the most important political players on the planet. I have read this book with great interest. I can only hope that the renaissance of China and its consequences won't have negative consequences. It is also a must-read for all those who wish to form their own opinion on the situation in which China has found itself. There is no better time to publish this book than now, when everyone in the world is talking about China, and Prof. Góralczyk brilliantly explains why it is so important. 